\title{
До 50-річчя від Дня народження професора С.лободяна Олександра Миколайовича
}

\begin{abstract}
Слободян Олександр Миколайович народився 30 травня 1971 року в м. Дрогобич Львівської області. Батько - Микола Костянтинович - інженер-механік, мати - Валентина Кузьмівна - медсестра.

Після закінчення восьми класів Дрогобицької середньої школи № 4 Олександр Миколайович вступив до медичного училища в м. Самбір на Львівщині. Після закінчення навчання працював на посаді медбрата поліклінічного відділення Дрогобицької центральної міської лікарні.

Упродовж 1990-1996 рр. навчався в Чернівецькому дер-
\end{abstract} жавному медичному інституті за спеціальністю “лікувальна справа”. Після завершення навчання вченою радою інституту був рекомендований на наукову роботу. 31996 до 1999 р. О. М. Слободян навчався в аспірантурі Чернівецького державного медичного інституту на кафедрі топографічної анатомії та оперативної хірургії.

Під керівництвом професора В. А. Малішевської у 2000 р. захистив кандидатську дисертацію на тему “Внутрішньоорганні взаємовідношення венозних структур печінки в пренатальному періоді онтогенезу людини”, після захисту якої відразу розпочав нові наукові дослідження в напрямку анатомічних особливостей перинатального періоду, результати яких згодом лягли в основу докторської дисертації. Докторську дисертацію “Закономірності морфогенезу дванадцятипалої кишки та підшлункової залози у перинатальному періоді” (науковий консультант професор Ю. Т. Ахтемійчук) захистив у 2009 р.

Упродовж 1999-2002 р. працював асистентом, з 2002-2009 р. - доцентом кафедри анатомії, топографічної анатомії та оперативної хірургії Буковинського державного медичного університету. 32009 р. - професор цієї ж кафедри. Вчене звання “доцент” отримав у 2003 році, “професор” - у 2013 році.

Професор О. М. Слободян широко відомий вчений-морфолог, видатний педагог та організа- тор вищої медичної школи. Коло його наукових інтересів охоплює значний діапазон проблем анатомії, клінічної анатомії та оперативної хірургії. Основний напрям наукових досліджень О. М. Слободяна - встановлення закономірностей морфометричних параметрів органів і структур у перинатальному періоді онтогенезу людини з метою визначення відповідності розвитку органів і структур до терміну вагітності, ступеня їхньої зрілості та прогнозування життєздатності плода, а також встановлення терміну вагітності. Свої наукові розробки впроваджує в стоматологію, неонатологію, педіатрію, судову медицину. Під його керівництвом виконують ряд дисертаційних робіт, які продовжують обраний напрямок.

Олександр Миколайович - автор понад 200 наукових праць, 4 навчальних посібників, 12 патентів на винаходи та корисні моделі, 15 раціоналізаторських пропозицій. Професор О. М. Слободян підготував 7 кандидатів медичних наук. Він є відповідальним секретарем науково-практичного медичного журналу “Клінічна анатомія та оперативна хірургія”.

Практичні заняття та лекції професора О. М. Слободяна мають успіх у студентів та викладачів кафедри. Йому притаманна ерудиція та професіоналізм, уміння цікаво, доступно викладати складні теми $з$ кафедральних навчальних дисциплін. Його постійно оточують студенти, аспіранти та молоді вчені, яким необхідна його підтримка, слушна порада, мудре слово та тепло великої людяності. Під керівництвом професора О. М. Слободяна постійно триває пошук нових методичних та педагогічних прийомів і підходів для покращення засвоєння знань студентами, підготовлено до друку нові навчальні та навчальнометодичні підручники та посібники.

Професор О. М. Слободян - член спеціалізованої вченої ради Д 58.601.01 у Тернопільському національному медичному університеті імені I. Я. Горбачевського МОЗ України із захисту докторських та кандидатських дисертацій зі спеціальності 14.03.01 - нормальна анатомія. Олек- 
сандра Миколайовича неодноразово запрошували і призначали офіційним опонентом на захисти докторських і кандидатських дисертацій у спеціалізованих радах інших медичних вузів України та Молдови.

За невеликий період науково-освітньої діяльності О. М. Слободян проявив неабияку наполегливість, працездатність і допитливість, став досвідченим педагогом і перспективним науковцем. "У нього зосередженість науковця, цілеспрямованість пошуковця, інтуїція дослідника, бо коли працює над якоюсь темою, то проникає в проблему, як астроном крізь ближчі орнаменти зір, як крізь срібне решето у віддалений простір. Зусиллям волі долає проблему, занурюючись у згустілий потаємний туманець”.
О. М. Слободян - порядна і чуйна людина. Користується заслуженим авторитетом та повагою серед співробітників кафедри та університету, його люблять і поважають студенти. Він безвідмовний у добрих справах, кожному прийде на допомогу, в біді порадить. На нього можна покластися, надійний, як “базальтова скеля”. Звичайно, життя - це суцільні перешкоди, але Олександр Миколайович завжди долає ці перешкоди. Мислення активізує його діяльність, прагнення і волю цього вченого, що яскраво реалізується в задуманому.

Щиросердечно вітаємо ювіляра, зичимо йому міцного здоров'я, довгих років життя, творчої наснаги, працездатності, злагоди, добробуту, подальших успіхів у науково-методичній діяльності та здійснення всіх запланованих намірів.

Професор М. С. Гнатюк, професор В. І. Півторак, професор В. В. Кошарний, професор В. С. Черно та колектив кафедри оперативної хірургії та клінічної анатомії Тернопільського національного медичного університету імені I. Я. Горбачевського МОЗ України 